\title{
Effects of Perennial Ryegrass Cultivars on Intake, Digestibility, and Milk Yield in Dairy Cows
}

\author{
B. M. Tas, ${ }^{1}$ H. Z. Taweel, ${ }^{1}$ H. J. Smit, ${ }^{2}$ A. Elgersma, ${ }^{2}$ J. Dijkstra, ${ }^{1}$ and S. Tamminga ${ }^{1}$ \\ ${ }^{1}$ Animal Nutrition Group, Department of Animal Sciences, Wageningen University, \\ $6700 \mathrm{AH}$, Wageningen, The Netherlands \\ ${ }^{2}$ Crop and Weed Ecology Group, Department of Plant Sciences, Wageningen University, \\ 6700 AK, Wageningen, The Netherlands
}

\begin{abstract}
The effects of 8 diploid perennial ryegrass (Lolium perenne L.) cultivars on dry matter (DM) intake, DM digestibility, and milk yield (MY) of dairy cows were evaluated in the summer of 2000 and 2001. Each summer, herbage was harvested daily and stall-fed to 12 dairy cows during six 2 -wk periods. Six cultivars were fed in 3 periods $(1,3$, and 5$)$ according to a double $3 \times$ 3 Latin square design. In the other periods $(2,4$, and 6), 2 cultivars were fed in a repeated measurement design. Herbage mass and leaf blades in the sward canopy varied among cultivars, but differences were not consistent between years. The largest differences in herbage composition were found in water-soluble carbohydrate content, followed by crude protein content. only small differences were found in the neutral detergent fiber (NDF) content. A higher water-soluble carbohydrate content was found in 2 cultivars in both years, whereas ranking of cultivars in crude protein and NDF content was not consistent with years. Dry matter intake and MY were not affected by cultivar. In both years, DM digestiblity was high $(>77 \%)$, with very small differences among cultivars in $2000(<0.5 \%)$ and larger differences in 2001 (up to $4 \%$ ). This was associated with a delayed heading date in 2001, resulting in larger differences in leaf blades and NDF content among cultivars. It may be concluded that the 8 cultivars used in our experiments do not provide grass breeders with encouraging evidence to include selection criteria for an increased DM intake, DM digestibility, and MY in their grass breeding schemes.
\end{abstract}

(Key words: perennial ryegrass, cultivar, intake, milk yield)

Abbreviation key: ADL = acid detergent lignin, DMD = dry matter digestibility, FPCM = fat- and protein-corrected milk, LS = Latin square, MPS = micro-

Received October 29, 2004.

Accepted April 20, 2005.

Corresponding author: B. Tas; e-mail: tas@aninut.uni-kiel.de. bial protein synthesis, $\mathbf{M Y}=$ milk yield, $\mathbf{N G R}=$ nonglucogenic to glucogenic ratio, WSC = water-soluble carbohydrate.

\section{INTRODUCTION}

In temperate areas of the world, intensively managed grasslands are dominated by perennial ryegrass. This grass has a high DM yield per hectare and provides feed for dairy cows of a high nutritive value at low costs. Because of the limited DMI of grass by highly productive dairy cows, the energy requirements for milk yield (MY) of these cows cannot be met by grass intake alone. Dry matter intake and DM digestibility (DMD) both determine the digestible DMI, which represents the amount of nutrients that can be absorbed and utilized by the dairy cow for MY. The DMI and DMD are interrelated; DMI seems to be the most important factor in determining digestible DMI (Waldo, 1986). It is known that digestibility of forages is strongly related to cell wall content (NDF) and its lignification (Van Soest, 1994). Neutral detergent fiber and acid detergent lignin (ADL) are thought to limit digestible DMI because of the physical fill of the gastrointestinal tract (Waldo, 1986), of which the rumen is supposed to be the most limiting compartment. Also, the absorbed nutrients from end products of microbial fermentation in the rumen and digestion in the small intestine may act as metabolic constraints in DMI (Illius and Jessop, 1996). From several trials with grazing cows, Chilibroste (1999) concluded that not one single factor, but a combination of physical and metabolic factors, constrain DMI.

The yield and nutritive value of perennial ryegrass are both determined by genetic factors (grass species and variety) and environmental factors (e.g., climate and weather conditions, soil type, fertilization level, grazing and cutting management). There are many different varieties of perennial ryegrass, and they vary in their sward canopy characteristics. Some researchers have reported small but consistent differences between grass varieties in in vitro disappearance (Reed and 
Sutherland, 1994; Beerepoot and Agnew, 1997); such findings indicate that there is potential for selection on this trait. Others focus more on the morphogenetic traits, such as leafiness and leaf length, to improve productivity of grass (Hazard et al., 1996), but also on the nutritive value and effect on intake with grazing animals (Carrère et al., 2001). Moreover, water-soluble carbohydrate (WSC) content of perennial ryegrass cultivars was found to be a consistent and heritable trait (Humphreys, 1989), and elevated WSC content increased the in vitro DM disappearance (Radojevic et al., 1994) and efficiency of microbial protein synthesis (MPS) in vitro (Lee et al., 2002) and resulted in a higher digestible DMI and MY by dairy cows (Miller et al., 2001). The focus of grass breeding has been mainly on sward and plant characteristics, but it is recognized that maximizing DMI and optimizing rumen function should be included in future breeding programs (Beever and Reynolds, 1995).

Therefore, the aim of this paper was to evaluate whether cultivars of diploid perennial ryegrass under similar management and growing conditions differ in their sward canopy characteristics and nutritive value and if the intake, digestibility, and MY of dairy cows are affected by cultivar. If significant and consistent differences were found among cultivars, there might be a potential for grass breeders not only to include sward canopy characteristics, but also nutritive value and effects on dairy cow's production in their breeding and selection schemes of new cultivars.

\section{MATERIALS AND METHODS}

\section{Herbage}

In autumn 1999, 8 diploid perennial ryegrass (Lolium perenne L.) cultivars ( 1 to 8 ) were sown on 3 adjacent paddocks with a clay soil. In summer 2000 and 2001, 2 feeding experiments were conducted in which grass cultivars were daily cut and fed to 12 highly productive Holstein-Friesian dairy cows. The individual DMI, apparent digestibility of the diet, and MY were measured. An adaptation period of $2 \mathrm{wk}$ preceded the experiments, which lasted 12 wk divided into 62 -wk periods. In 2000 , the experiment was conducted from June 28 to September 15; in 2001, the experiment was conducted from July 7 to September 20. Cultivars 1, 2, 3, 4, 5, and 6 were fed in periods 1,3 , and 5; cultivars 7 and 8 were fed in periods 2,4 , and 6 .

The 8 cultivars were selected from the Dutch List of Recommended Varieties (Bonthuis and Donner, 2001). Cultivars $1,2,6,7$, and 8 were chosen from the intermediate heading date class; heading dates ranged from May 25 to June 1 . Cultivars 3, 4, and 5 were chosen from the late heading date class, and heading dates ranged from June 7 to 10 . In order of heading date, these cultivars were Abergold, Respect, Agri, Barlet, Magella, Herbie, Barezane, and Barnhem. These cultivars further varied in herbage yield, persistency, winter hardiness, and crown rust resistance. One cultivar was also chosen because it was selected for an elevated WSC content. Moreover, cultivars 7 and 8 were selected because cultivar 7 showed a $2 \%$ higher in vitro digestibility than cultivar 8 (Beerepoot and Agnew, 1997), and this will be compared with the in vivo digestibility measured in the experiments.

Cultivars 1 to 6 were sown on paddock A, which was previously cultivated with grass seed. This paddock was divided into 21 blocks, and each block was divided in 6 strips. Within each block, the 6 cultivars were assigned at random to a strip. Cultivars 7 and 8 were sown on paddock B, which was previously cultivated with barley. This paddock was divided in 19 blocks, and each block was divided in 2 strips. At random, cultivars 7 and 8 were assigned to one of the 2 strips within a block. On the third paddock. Paddock C, cultivars 1 to 6 and cultivars 7 and 8 were sown in similar designs as on paddocks $\mathrm{A}$ and $\mathrm{B}$, respectively.

\section{Animals}

Each year, 12 Holstein-Friesian dairy cows were used with the approval of the Experimental Animals Committee of Wageningen University. In 2000, all cows were multiparous, ranging from their second to tenth lactation and an expected 305-d fat- and protein-corrected milk (FPCM) yield of $8379 \pm 250 \mathrm{~kg} / 305 \mathrm{~d}$. At the start of the experiment, cows were $118 \pm 11$ DIM, and BW was $587 \pm 12 \mathrm{~kg}$. In 2001, 6 heifers and 6 multiparous cows in their second and third lactations were used. The heifers had an expected FPCM of 7776 $\pm 185 \mathrm{~kg} / 305 \mathrm{~d}$, were $140 \pm 16 \mathrm{DIM}$, and their BW was $522 \pm 14 \mathrm{~kg}$. The average expected FPCM of the multiparous cows was $9053 \pm 607 \mathrm{~kg} / 305 \mathrm{~d}$; cows were $115 \pm 17 \mathrm{DIM}$, and BW was $571 \pm 17 \mathrm{~kg}$ at the start of the experiment.

\section{Herbage Cutting and Sampling}

The number of regrowth days of the grass (20 to $30 \mathrm{~d}$ ) was adjusted to obtain a herbage mass of approximately $2000 \mathrm{~kg}$ of DM/ha. In 2000, N fertilization was between 38 and $48 \mathrm{~kg}$ of N/ha per cut. In 2001, N fertilization was increased and ranged from 53 to $100 \mathrm{~kg}$ of N/ha per cut to stimulate grass growth, because growing conditions were less favorable than in 2000 (i.e., higher mean temperatures and lower rainfall) (Table 1). The grass was mown daily between 1300 and $1500 \mathrm{~h}$ at 5 $\mathrm{cm}$ above ground level, and the herbage mass ( $\mathrm{kg}$ of 
Table 1. Weather conditions during the regrowth periods [average daily irradiation $\left(\mathrm{MJ} / \mathrm{m}^{2}\right.$ per d), average daily temperature $\left({ }^{\circ} \mathrm{C}\right)$, and total rainfall $\left.(\mathrm{mm})\right]$ and the total days of regrowth and $\mathrm{N}$ fertilization $(\mathrm{kg}$ of $\mathrm{N} / \mathrm{ha}$ ) per cut in the 6 periods: and the mean of periods 1, 3, and 5 (cultivars 1 to 6 ); and the mean of periods 2,4 , and 6 (cultivars 7 and 8) in 2000 and 2001.

\begin{tabular}{|c|c|c|c|c|c|c|c|c|}
\hline & \multicolumn{6}{|c|}{ Period } & \multirow{2}{*}{$\begin{array}{l}\text { Mean } \\
\text { of periods } \\
1,3 \text {, and } 5\end{array}$} & \multirow{2}{*}{$\begin{array}{l}\text { Mean } \\
\text { of periods } \\
2,4 \text {, and } 6\end{array}$} \\
\hline & 1 & 2 & 3 & 4 & 5 & 6 & & \\
\hline \multicolumn{9}{|l|}{2000} \\
\hline Irradiation, $\mathrm{MJ} / \mathrm{m}^{2}$ per $\mathrm{d}$ & 18.6 & 15.1 & 15.4 & 16.0 & 16.0 & 12.5 & 16.7 & 14.5 \\
\hline Temperature, ${ }^{\circ} \mathrm{C}$ & 16.3 & 14.4 & 15.8 & 17.9 & 17.2 & 16.0 & 16.4 & 16.1 \\
\hline Total rainfall, mm & 63 & 85 & 72 & 51 & 21 & 16 & 52 & 51 \\
\hline Regrowth days & 22 & 24 & 23 & 24 & 27 & 27 & 24 & 25 \\
\hline $\mathrm{N}$ fertilization, $\mathrm{kg}$ of $\mathrm{N} / \mathrm{ha}$ & 48 & 48 & 41 & 40 & 38 & 40 & 42 & 43 \\
\hline \multicolumn{9}{|l|}{2001} \\
\hline Irradiation, $\mathrm{MJ} / \mathrm{m}^{2}$ per $\mathrm{d}$ & 20.1 & 17.2 & 17.8 & 16.9 & 15.6 & 12.0 & 17.8 & 15.4 \\
\hline Mean temperature, ${ }^{\circ} \mathrm{C}$ & 18.1 & 18.0 & 18.5 & 18.5 & 18.0 & 15.3 & 18.2 & 17.3 \\
\hline Total rainfall, mm & 12 & 58 & 18 & 12 & 3 & 24 & 11 & 31 \\
\hline Regrowth days & 29 & 27 & 19 & 24 & 21 & 26 & 23 & 26 \\
\hline $\mathrm{N}$ fertilization, $\mathrm{kg}$ of $\mathrm{N} / \mathrm{ha}$ & 100 & 53 & 55 & 76 & 81 & 59 & 79 & 63 \\
\hline
\end{tabular}

$\mathrm{DM} / \mathrm{ha}$ ) was determined. One sample of the herbage was taken by hand for analyses of morphology of the sward canopy by determining percentages of leaf, stem, pseudo-stem, and dead material based on DM weight. Another herbage sample was taken with a grass core (i.d. $=3 \mathrm{~cm}$ ) and oven-dried at $70^{\circ} \mathrm{C}$ to determine $\mathrm{DM}$ content. One-half of the amount of grass to be fed was stored in the barn at room temperature; the other half was stored in a cooling unit at $4^{\circ} \mathrm{C}$ overnight until feeding the next morning.

\section{Animal Housing, Feeding, and Sample Collection}

Cows were housed in a tie stall, where temperature was maintained between 15 and $20^{\circ} \mathrm{C}$. Drinking water was always available. Cows received fresh grass for ad libitum intake. Each day, from $1500 \mathrm{~h}$ onward, the grass stored in the barn at room temperature was fed. At $0600 \mathrm{~h}$ the next morning, orts were removed, and the grass stored in the cooling unit was fed. In addition, a concentrate feed $(4.1 \mathrm{~kg}$ of DM/d in 2000 and $2.5 \mathrm{~kg}$ of $\mathrm{DM} / \mathrm{d}$ in 2001) was fed. In both years, the ingredient composition of the conentrate mixture was beet pulp (21.0\%), maize (21.0\%), barley (21.0\%), soybean hulls (11.5\%), coconut peels $(10.0 \%)$, beet molasses $(8.0 \%)$, and Argentinian soya (7.5\%). The OM, CP, NDF, and ADL contents of concentrate feed in 2000 were 941.1, $154.5,230.8$, and $20.3 \mathrm{~g} / \mathrm{kg}$ of DM, respectively, and in 2001 , these contents were $941.6,135.1,259.1$, and 20.9 $\mathrm{g} / \mathrm{kg}$ of DM, respectively. Orts were collected daily, and DM content was determined. Individual DMI was calculated by subtracting the DM weight of orts from the DM weight of grass fed to the cows. During milking, concentrate feed was fed in 2 equal portions. Cows were milked twice daily at 0600 and $1600 \mathrm{~h}$, and individual MY was recorded $(\mathrm{kg} / \mathrm{d})$. Daily individual milk samples were taken and fat and protein contents were determined. The FPCM was calculated as $[0.337+0.116 \times$ fat $(\%)+0.06 \times$ protein $(\%)] \times$ MY. Cows were weighed once every period. Individual apparent digestibility of $\mathrm{DM}, \mathrm{OM}, \mathrm{CP}$, and NDF of the diet was determined by quantitative collection of the feces of each cow on $d 11$, 12,13 , and 14 of each period. In 2000, daily feces was collected in two 3 -h periods, and in 2001 , daily feces was collected during one $6-h$ period. In both years, feces samples were collected for, in total, $24 \mathrm{~h}$, covering one full day. The total amount of feces excreted by each cow was weighed, and a sample of 3\% (2000) and 5\% (2001) of fresh weight was taken, added to a pooled sample per cow per period, and stored at $-20^{\circ} \mathrm{C}$.

\section{Sample Handling and Chemical Analysis}

The oven-dried grass samples of $d 10,11,12$, and 13 in each period of each cultivar were ground through a 1-mm sieve. These samples were pooled based on equal DM weight and analyzed for DM, inorganic matter (ash), $\mathrm{CP}(6.25 \times \mathrm{N}), \mathrm{NDF}, \mathrm{ADL}$, and WSC. The frozen feces samples were thawed overnight, and in the fresh feces, the contents of DM and CP were determined. Subsequently, subsamples were taken, freeze-dried, ground through a 1-mm sieve, and analyzed for DM, ash, NDF, and ADL content.

The DM was determined by drying at a constant weight at $103^{\circ} \mathrm{C}$ (ISO 6496), and ash was determined by combustion at $550^{\circ} \mathrm{C}$ (ISO 5984). Nitrogen was determined following ISO 5983 with $\mathrm{CuSO}_{4}$ as the catalyst. Neutral detergent fiber and ADL were analyzed according to a modified method of Van Soest described by Goelema et al. (1998). Water-soluble carbohydrates were analyzed by determination of the content of reducing sugars (van Vuuren et al., 1993), but water instead 
of ethanol was used for extraction. This alteration of the method had been tested and was equivalent (van Lonkhuijsen and Cone, 1992). Milk fat and protein content were determined (IDF 141) at the Melkcontrolestation (Zutphen, The Netherlands).

\section{Experimental Design and Statistical Analyses}

Herbage mass and morphology of the sward canopy were analyzed using data from d 6 to 13 in each period. Chemical composition of the grass was determined in a pooled sample from d 10 to 13 in each period. The DMI and MY per cow in each period were calculated as the mean of $d 6$ to 13 in each period. Digestibility was calculated based on d 10 to 13 (when feces was collected), and these days corresponded with the sampling days of the herbage. Data from herbage mass and sward canopy were analyzed with cultivar and period as independent variables and days within period as repeated measurements. These data of cultivars 1,2 , and 3 ; of cultivars 4,5 , and 6 ; and of cultivars 7 and 8 were analyzed separately, in agreement with animal data. The 12 cows were divided in 2 groups of 6 cows, based on parity, and within each group, cows were ranked on pre-experimental FPCM. In 2001, there was a group of heifers and a group of multiparous cows. Cows from different groups with equal ranking numbers were assigned to a pair of cows. At random, one of the 2 cows of each pair was assigned to cultivar 7 and the other to cultivar 8 . The experimental design was a stratified block design with repeated measurements with cultivar and period as independent variables. Cultivars 1 to 6 were analyzed according to 2 Latin squares (LS), where in LS 1 cultivars 1 , 2, and 3 and in LS 2 cultivars 4, 5, and 6 were fed in 3 periods to 6 cows. At random, 3 pairs of cows were assigned to LS 1 and 3 pairs were assigned to LS 2 . The independent variables in each LS were cultivar, period, and cow. All data were analyzed using the GLM procedure of SAS 6.12 (SAS, 1989), level of significance was $\alpha=0.05$, and the Tukey test was used to test for all pairwise comparisons among means.

\section{RESULTS AND DISCUSSION}

\section{Sward Canopy}

Weather conditions varied within and between years as shown in Table 1. In 2001, June and July were relatively warm, and the rainfall was low, which decreased the herbage growth rate. Therefore, $\mathrm{N}$ fertilization and/ or regrowth days were increased in these periods. The $\mathrm{N}$ fertilization level per cut was higher in 2001 (20 to $40 \mathrm{~kg}$ of $\mathrm{N}$ per cut) than in 2000 and differed in 2001 between the 2 paddocks.
The sward canopy and the chemical composition of the 8 cultivars in 2000 and in 2001 are presented in Table 2 . In 2000, herbage mass varied slightly among the cultivars and ranged from 1993 to $2238 \mathrm{~kg}$ of DM/ ha. Herbage mass of cultivar 8 was higher $(P<0.05)$ than that of cultivar 7 . The mean herbage mass was slightly higher in 2001, with a similar range but not ranking among cultivars. In 2001, herbage mass of cultivar 4 was higher $(P<0.05)$ than that of cultivar 6 . In contrast with 2000 , cultivars 7 and 8 had a very similar herbage mass in 2001. The relative differences among cultivars in herbage mass were similar as in the Dutch List of recommended varieties (Bonthuis and Donner, 2001), although ranking of cultivars was not similar. The higher herbage mass in the second year might have been caused by a combination of a 1-yr older sward with a higher tiller density (data not shown) and a 100$\mathrm{kg} / \mathrm{yr}$ higher $\mathrm{N}$ fertilization.

In both years, cultivars varied in their percentage of leaf blades. In 2000, cultivar 3 tended to have a higher $(P=0.07)$ percentage of leaf blades than cultivar 2 , but in 2001, cultivar 3 had the lowest $(P<0.05)$ percentage of leaf blades. A similar contrast between years was found in LS 2: cultivar 4 had a higher $(P<0.05)$ percentage of leaf blades in 2000, whereas in 2001, cultivar 6 had a higher $(P<0.05)$ percentage of leaf blades than the other cultivars. The lower percentage of leaf blades in 2001 than in 2000 and the different ranking of cultivars may be associated with grassland management between the experiments. In winter and spring, sheep continuously grazed the paddocks, and this might have affected grass growth and retarded the heading dates of the (according to the List of Recommended Varieties) earlier heading-date cultivars.

\section{Grass Composition}

In Table 2, the chemical compositions of the cultivars in 2000 and in 2001 are presented. In 2000, the 6 cultivars differed slightly $(P<0.04)$ in their $\mathrm{CP}$ content and had a relatively high WSC content; larger differences among cultivars (>40 g/kg of DM) were found in WSC content than in CP content. Two cultivars ( 1 and 4$)$ had a higher $(P<0.01)$ WSC content and a slightly lower NDF content (LS 1: $P<0.01$ and LS 2: $P=0.06$ ) than the other cultivars. Chemical composition of cultivars 7 and 8 was very similar, with a small difference $(P<$ $0.05)$ in $\mathrm{CP}$ content. The relatively high CP content of cultivars 7 and 8 compared with the other 6 cultivars was associated with a lower WSC content. The ADL content was low and did not differ significantly among cultivars. In $2001, \mathrm{CP}$ content varied slightly $(P>0.05)$ among the cultivars in both LS. In line with the observations in 2000 , cultivar 7 had a slightly higher $(P<0.05)$ 
Table 2. Mean herbage mass (HM), percentage of leaf blades in the sward canopy, and chemical composition of 8 perennial ryegrass cultivars harvested during 2 consecutive summers (2000 and 2001). ${ }^{1}$

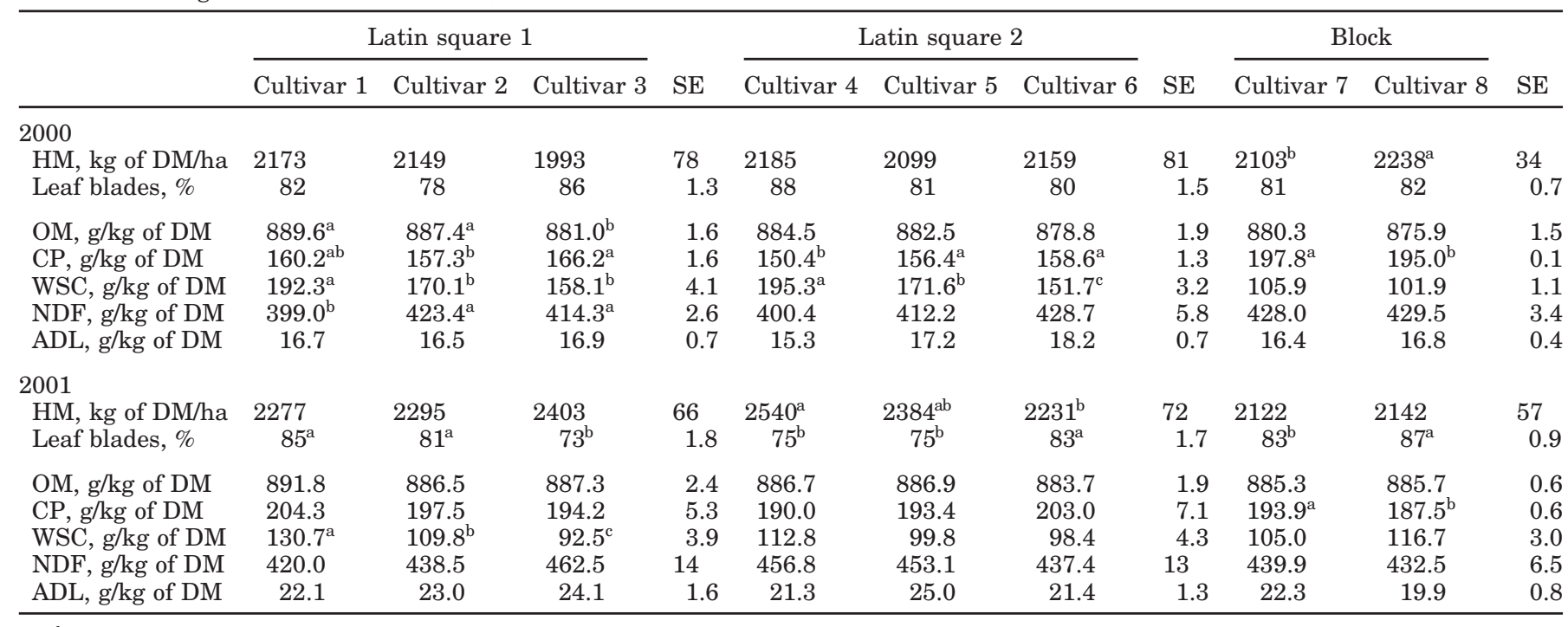

${ }^{\mathrm{a}, \mathrm{b}, \mathrm{c}}$ Means of cultivars within a row and Latin square or block with different superscripts $\operatorname{differ}(P<0.05)$.

${ }^{1} \mathrm{WSC}=$ Water-soluble carbohydrate; $\mathrm{ADL}=$ acid detergent lignin.

$\mathrm{CP}$ content than cultivar 8 . The WSC content ranged from 92.5 to $130.7 \mathrm{~g} / \mathrm{kg}$ of DM with a 20 - to almost $40-\mathrm{g} / \mathrm{kg}$ of DM higher WSC content of cultivar 1 than cultivars 2 and 3 . In LS 2 , the difference in WSC content between cultivar 4 and cultivars 5 and 6 was less than that in 2000 and also was not significant $(P=0.13)$. Cultivar differences in NDF and ADL content were relatively small and not significant.

In 2000 , the mean $\mathrm{N}$ fertilization per cut was similar (Table 1), but the CP content of cultivars 7 and 8 was higher than that of the other 6 cultivars. A possible explanation may be a different $\mathrm{N}$ supply from the soil between the 2 paddocks because of different crops and fertilization management in years prior to the experiments. The higher CP content of the 6 cultivars in 2001 than in 2000 was most likely associated with the higher $\mathrm{N}$ fertilization level in 2001 (79 kg of $\mathrm{N}$ per cut) compared with 2000 (42 kg of $\mathrm{N}$ per cut). In contrast, $\mathrm{CP}$ content of cultivars 7 and 8 was almost similar in both years, whereas in 2001, the mean fertilization level was $20 \mathrm{~kg}$ of $\mathrm{N}$ per cut higher than in 2000. The higher mean CP content in 2001 was associated with a lower mean WSC content, in agreement with the known inverse relationship between CP and WSC content (e.g., Wilman and Wright, 1978; Valk et al., 2000). This inverse relationship was, however, observed between years and also between paddocks in 2000, but was absent within cultivars, in agreement with Radojevic et al. (1994). The mean NDF content was slightly increased in 2001 in comparison with 2000 , which was associated with the relatively high percentage of stems in the sward canopy in the first 2 periods in 2001 as mentioned before. This was also shown in an increased ADL:NDF ratio, which was on average 50.6 and $40.2 \mathrm{~g}$ of ADL/kg of NDF in 2000.

In both years, the differences among cultivars in chemical composition were relatively largest for WSC content, intermediate for CP content, and smallest for NDF content. Moreover, cultivars 1 and 4 had, in both years, the highest WSC content; cultivars 3 and 6 had the lowest. A similar ranking of cultivars for WSC content between years led Humphreys (1989) to conclude that WSC content was a consistent and heritable trait.

\section{DMI and Digestibility}

The intake and digestibility of the cultivars in 2000 and in 2001 are presented in Table 3. In 2000, the mean DMI of herbage was $16.6 \pm 0.2 \mathrm{~kg} / \mathrm{d}$ with an additional $4.1 \mathrm{~kg} / \mathrm{d}$ of concentrate feed. There were only small $(\leq 1.2 \mathrm{~kg} \mathrm{DM} / \mathrm{d})$ and non-significant differences $(P>0.05)$ among the cultivars. Cultivars 1 and 4 , with the higher WSC content, had the lowest DMI $(P>0.05)$. The apparent digestibilities of $\mathrm{DM}, \mathrm{OM}$, and NDF were high $(>80 \%)$ for all diets and, assuming that the digestibility of the concentrate part of the diet was not affected by cultivar, the cultivars varied only slightly $(P>0.05)$ in their digestibility. In 2001, the herbage DMI was 14.4 $\pm 0.2 \mathrm{~kg} / \mathrm{d}$, and cows were supplemented $2.5 \mathrm{~kg}$ of DM/ $\mathrm{d}$ of concentrate feed. Differences among cultivars in herbage DMI were small, within $1 \mathrm{~kg} \mathrm{DM} / \mathrm{d}$, and not significant. The apparent digestibility of the diet was 


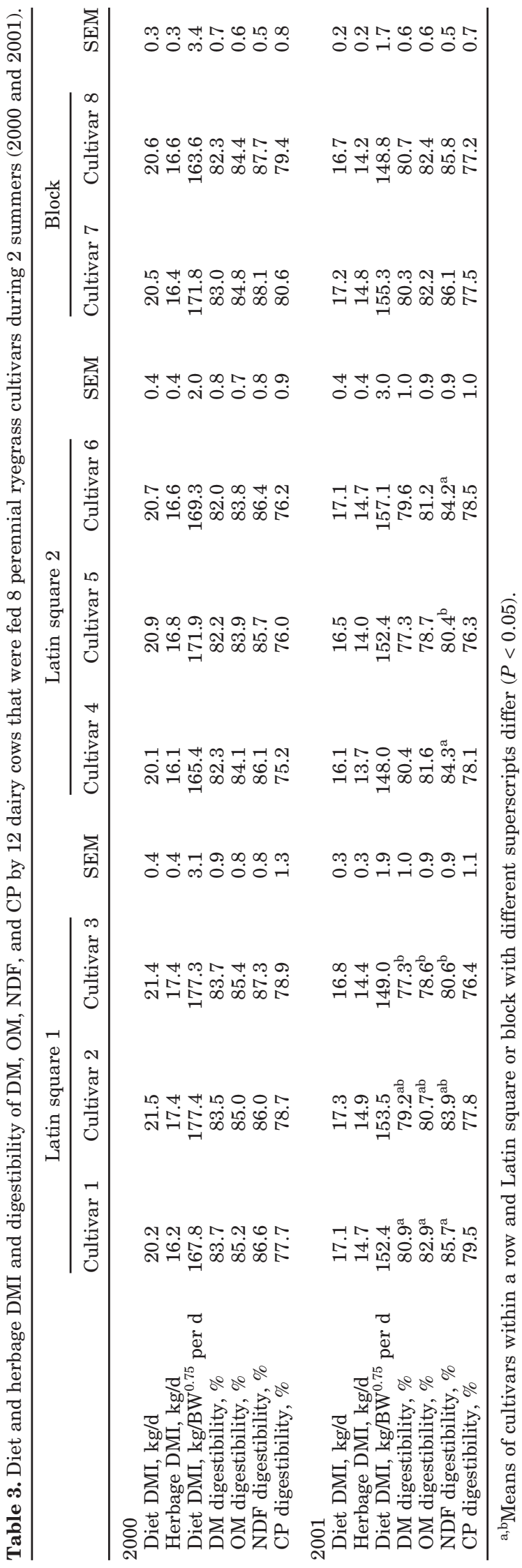

high $(>77 \%)$, and cultivars differed up to $6 \%$ in average NDF digestibility. The lower mean NDF digestibility of diets with cultivars 3 and $5(P<0.03)$ were related to the lower percentage of leaf blades and higher NDF and ADL contents in the first period, as the NDF digestibility was lower in this period. This effect was not found for the diet with cultivar 4 , with a similar percentage of leaf blades and NDF content as the diets containing cultivars 3 and 5 in the first period. Therefore, the lignification of the cell walls may be an explanation as the ADL:NDF ratio of cultivars 1, 2, 4, and 6 was approximately $54 \mathrm{~g} / \mathrm{kg}$, but this ratio was higher for cultivars 3 and 5 with 60 and $64 \mathrm{~g} / \mathrm{kg}$, respectively. The $2 \%$ higher in vitro disappearance of cultivar 7 in comparison with cultivar 8 , as found by Beerepoot and Agnew (1997), was not found in vivo in our experiments.

The regulation of intake by the animal has been the topic of many experiments, and the general concept is that intake is under an integrated physical and metabolic control, depending on diet characteristics and physiological state of the animal (Forbes, 1996). Physical control depends on the fill capacity of the gastrointestinal tract, which, in general, is found to be inversely related to NDF content of forages (i.e., grass and legumes) (Waldo, 1986; Mertens, 1994). In both years, DMI was negatively and weakly related to NDF content, most likely because of the small differences in NDF content among cultivars. Moreover, NDF of the total diet was highly digestible ( $>80 \%)$ for all cultivars. Therefore, cultivars with a higher DMI resulted in a higher NDF intake, and, thus, physical fill of the gastrointestinal tract did not seem to limit DMI among cultivars within an experiment. Moreover, no differences were found in the rate and extent of degradation of NDF in the rumen (Taweel et al., 2004; Tas, 2005), as this might affect the DMI (Forbes, 1996). The high digestibilities and small differences in DMD among cultivars did not affect DMI in agreement with Valk et al. (2000). Miller et al. (2001) found a higher digestible DMI $(P<0.05)$ of a cultivar with a high WSC content in comparison with a cultivar with a normal WSC content, which was explained by the difference in WSC content and digestible fiber. Our results suggested an opposite effect: cultivars 1 and 4 (with the higher WSC contents) had the lowest DMI in 2000, and cultivar 4 also had the lowest DMI in 2001. Grass differing in WSC content did not influence DMI with indoor feeding (Valk et al., 2000) or with rotational grazing (Orr et al., 1997). Therefore, increased WSC content in grass does not seem to increase daily DMI. The small differences in CP content were not related to differences in DMI, which is in agreement with van Vuuren et al. (1992) and Valk et al. (2000) with grass that had larger differences in CP content. 


\section{MY and Milk Composition}

Mean MY and composition of the cultivars in 2000 and in 2001 are presented in Table 4 . In 2000, cultivars showed small $(<2 \mathrm{~kg} / \mathrm{d})$ and nonsignificant differences in MY. The FPCM and milk fat yield were, however, higher for cultivar 2 than for cultivar 3. In 2001, MY and FPCM among cultivars varied $(P>0.05)$ only slightly $(<1.5 \mathrm{~kg} / \mathrm{d})$. In LS 1 , small differences in milk fat $(P=0.03)$ and protein content $(P=0.02)$ among the 3 cultivars were found. Comparing both years, cows on cultivars 3 and 4 produced the lowest amount of milk, and cows on cultivars 2 and 6 produced the highest amount. Differences in MY and composition between cultivars 7 and 8 were small, and results were inconsistent when both years were compared.

The digestible DMI and the chemical composition of the diet determined both the amount and type of nutrients available for MY. A positive linear relationship between DMI and MY within years $\left(\mathrm{R}^{2}=0.44\right.$ in 2000 and $R^{2}=0.40$ in 2001) was found. The conversion of the diet into milk varied $(P>0.05)$ among cultivars (up to $6 \%$ in 2000), but in both years, no significant cultivar effect was present.

The composition of the diet may have an effect on the yield and content of milk fat and protein. The main end product of NDF fermentation in the rumen is acetate, which is a precursor of milk fat synthesis. The milk fat yields differed only slightly, most likely because of small differences in NDF content and NDF intakes. In general, dietary effects on milk protein content are much smaller than effects on milk fat content (DePeters and Cant, 1992). The milk protein yield may be stimulated by higher propionate production by rumen fermentation, a higher amount of glucose absorption in the small intestine, or higher amino acid absorption in the small intestine. Increasing the WSC content in the diet may increase the proportion of propionate and butyrate and reduce acetate and the nonglucogenic to glucogenic ratio (NGR) in the rumen (Lee et al., 2002). In our experiments, the NGR was lower $(P=0.04)$ for cultivar 1 than for cultivars 2 and 3 in 2000, but this effect was absent in 2001 with a similar difference in WSC content. Moreover, in both years, cultivar 4, with a higher WSC content, did not show a lower NGR than cultivars 5 and 6 (Taweel et al., 2004). Amounts of glucose absorbed from the small intestine are likely small, as all WSC are assumed to be degraded in the rumen and the starch content of the total diet is small. Amino acids in the small intestine can originate from RUP from the feed and from rumen microbial protein. Differences among cultivars in RUP were small (Tas, 2005) and, therefore, do not seem to explain differences among cultivars in milk protein. A more efficient micro-

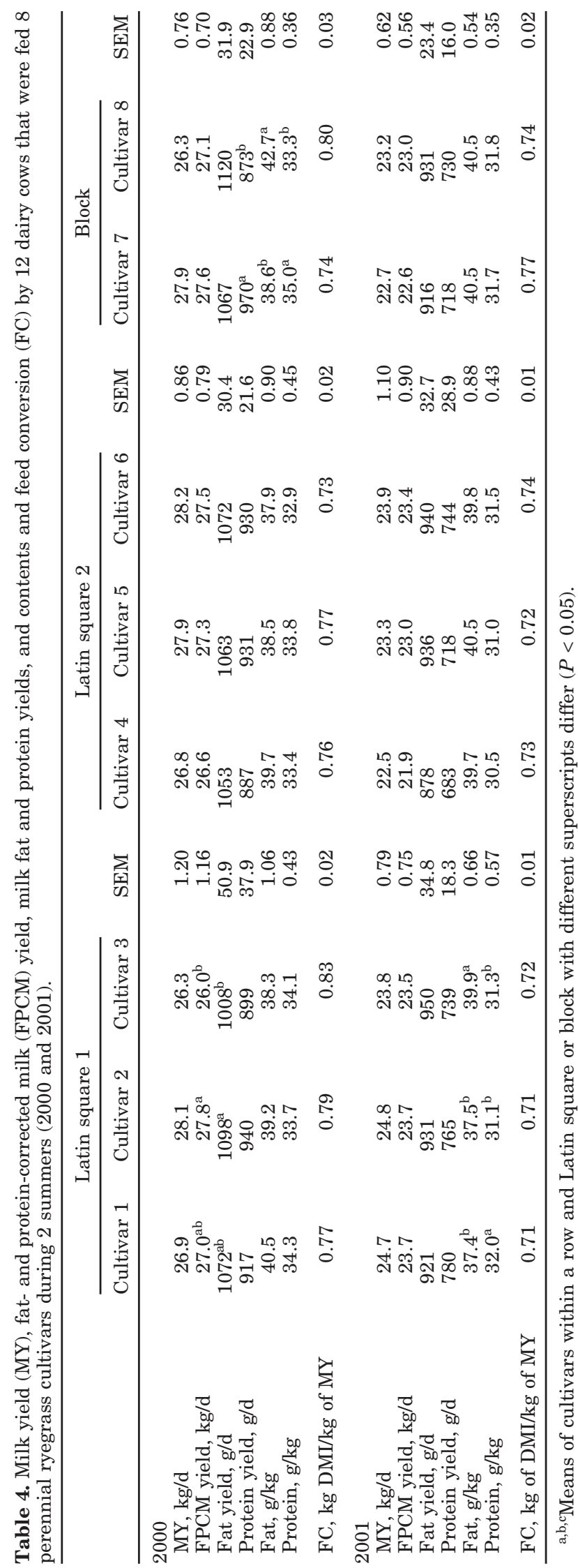


bial protein synthesis (MPS) may increase the amount of microbial protein synthesized in the rumen and, thus, the amount that flows to the small intestine, where the microbial protein will be digested and absorbed and provide more amino acids available for milk protein synthesis. The MPS depends on the $\mathrm{N}$ and energy supply for the microbes in the rumen. Within grass, an increased WSC content is believed to supply readily available energy next to the readily degradable CP. This is believed to increase the efficiency of MPS in the rumen. However, Dijkstra et al. (1998) argued that in diets with a sufficient CP content, an improved balance between degradable energy and $\mathrm{N}$ is unlikely to increase the efficiency of MPS. According to Miller et al. (2001), the assumed increased efficiency could explain the differences found in MY between cultivars differing (39 $\mathrm{g} / \mathrm{kg}$ of DM) in WSC content, but Lee et al. (2002) did not show a more efficient MPS with even larger differences in WSC content ( $83 \mathrm{~g} / \mathrm{kg}$ of $\mathrm{DM}$ ) between cultivars. Although the WSC content of cultivar 1 and 4 was higher than the other cultivars, the digestibilities did not differ, indicating that there was not a higher MPS because of elevated levels of degradable carbohydrates in the rumen. Moreover, in our experiments, the DMI and the efficiency of MPS might have had a confounding effect on the amount of microbial protein synthesized, which might have reduced the effect of the differences in chemical composition of the cultivars on microbial protein and milk fat and protein yields and contents.

\section{CONCLUSIONS}

In both years, herbage mass, percentage of leaf blades, and chemical composition varied slightly among the cultivars. The largest differences among cultivars in herbage composition were found in WSC content, followed by CP content. Only small differences were found in the NDF content. A higher WSC content was found in 2 cultivars in both years, whereas ranking of cultivars in $\mathrm{CP}$ and NDF content was not consistent with years. The DMI and DMD by the dairy cows were not affected by the cultivar that was fed. Digestibility of NDF in 2001 was lower for 2 cultivars with a delayed heading date, lower percentage of leaf blades, and higher NDF and ADL contents. There was no effect of cultivar found on the MY, and only small differences among cultivars were found on the milk fat and protein content and yield. Based on these results, it may be concluded that the 8 cultivars used in these 2 experiments do not provide grass breeders with encouraging evidence to include selection criteria for an increase in DMI, digestibility, and MY in their grass breeding schemes.

\section{ACKNOWLEDGMENTS}

The authors thank the personnel of the experimental farms "De Ossekampen" and "Unifarm," the laboratory of Animal Nutrition and graduate students for their assistance in conducting the experiments, sample handling, and carrying out proximate analyses. The financial support of the Ministry of Economic Affairs (Senter, The Hague, The Netherlands) and Barenbrug Holland BV (Oosterhout, The Netherlands) is greatly acknowledged.

\section{REFERENCES}

Beerepoot, L. J., and R. E. Agnew. 1997. Breeding for improved herbage quality in perennial ryegrass. Page 31 in Seeds of progress. Proc. BGS BSPB NIAB SAC Conf., Nottingham, UK. BGS, Reading, UK.

Beever, D. E., and C. K. Reynolds. 1994. Forage quality, feeding value and animal performance. Grassland and society. Pages 48-60 in Proc. 15th Gen. Mtg. Eur. Grassl. Fed., Wageningen Pers, Wageningen, The Netherlands.

Bonthuis, H., and D. A. Donner. 2001. Pages 77-134 in 77th List of Varieties of Field Crops 2002. Plant Res. Int., B.V. Wageningen, The Netherlands.

Carrère, P., F. Louault, P. C. de Fachio Carvalho, M. Lafarge, and J. F. Soussana. 2001. How does the vertical and horizontal structure of a perennial ryegrass and white clover sward influence grazing? Grass Forage Sci. 56:118-130.

Chilibroste, P. 1999. Grazing time: The missing link. A study of the plant-animal interface by integration of experimental and modelling approaches. Ph.D. Diss., Agricultural Univ., Wageningen, The Netherlands.

DePeters, E. J., and J. P. Cant. 1992. Nutritional factors influencing the nitrogen composition of bovine milk: A review. J. Dairy Sci. 75:2043-2070.

Dijkstra, J., J. France, and S. Tamminga. 1998. Quantification of the recycling of microbial nitrogen in the rumen using a mechanistic model of rumen fermentation processes. J. Agric. Sci. 130:81-94.

Forbes, J. M. 1996. Integration of regulatory signals controlling forage intake in ruminants. J. Anim. Sci. 74:3029-3035.

Goelema, J. O., M. A. M. Spreeuwenberg, G. Hof, A. F. B. van der Poel, and S. Tamminga. 1998. Effect of pressure toasting on the rumen degradability and intestinal digestibility of whole and broken peas, lupins and faba beans and a mixture of these feedstuffs. Anim. Feed Sci. Technol. 76:35-50.

Hazard, L., M. Ghesquiere, and C. Barraux. 1996. Genetic variability for leaf development in perennial ryegrass populations. Can. J. Plant Sci. 76:113-118.

Humphreys, M. O. 1989. Water-soluble carbohydrates in perennial ryegrass breeding. II. Cultivar and hybrid progeny performance in cut plots. Grass Forage Sci. 44:237-244.

Illius, A. W., and N. S. Jessop. 1996. Metabolic constraints on voluntary intake in ruminants. J. Anim. Sci. 74:3052-3062.

Lee, M. R. F., L. J. Harris, J. M. Moorby, M. O. Humphreys, M. K. Theodorou, J. C. MacRae, and N. D. Scollan. 2002. Rumen metabolism and nitrogen flow to the small intestine in steers offered Lolium perenne containing different levels of water-soluble carbohydrate. J. Anim. Sci. 74:587-596.

Mertens, D. R. 1994. Regulation of forage intake. Pages 450-493 in Natl. Conf. Forage Quality, Evaluation, and Utilization. G. C. Fahey, M. Collins, D. R. Mertens, and L. E. Moser, ed. Univ. Nebraska, Lincoln. Am. Soc. Agron., Crop Sci. Soc. Am., Soil Sci. Soc. Am., Madison, WI.

Miller, L. A., J. M. Moorby, D. R. Davies, M. O. Humphreys, N. D. Scollan, J. C. MacRae, and M. K. Theodorou. 2001. Increased concentration of water-soluble carbohydrate in perennial ryegrass (Lolium perenne): Milk production from late-lactation dairy cows. Grass Forage Sci. 56:383-394. 
Orr, R. J., P. D. Penning, A. Harvey, and R. A. Champion. 1997. Diurnal patterns of intake rate by sheep grazing monocultures of ryegrass or white clover. Appl. Anim. Behav. Sci. 52:65-77.

Radojevic, I., R. J. Simpson, J. A. St. John, and M. O. Humphreys. 1994. Chemical composition and in vitro digestibility of lines of Lolium perenne selected for high concentrations of water-soluble carbohydrate. Aust. J. Agric. Res. 45:901-912.

Reed, K. F. M., and G. Sutherland. 1994. Improved grass cultivars increase milk and meat production-A review. N.Z. J. Agric. Res. $37: 277-286$

SAS/STAT. 1989. SAS/STAT User's Guide, Version 6. Vol. 2. 4th ed. SAS Inst. Inc., Cary, NC.

Tas, B. M. 2005. Perennial ryegrass for dairy cows: Intake, milk production and nitrogen utilization. Ph.D. Diss., Wageningen University, The Netherlands.

Taweel., H. Z. H. 2004. Perennial ryegrass for dairy cows: Grazing behaviour, intake, rumen function and performance. $\mathrm{Ph}$. D. Diss., Wageningen Univ., Wageningen, The Netherlands.

Valk, H., I. E. Leusink Kappers, and A. M. van Vuuren. 2000. Effect of reducing nitrogen fertilizer on grassland on grass intake, di- gestibility and milk production of dairy cows. Livest. Prod. Sci. 63:27-38.

van Lonkhuijsen, H. J. and J. W. Cone. 1992. Ontwikkeling van een protocol voor de analyse van niet-zetmeel koolhydraten. Pages 19-36 in Niet-zetmeel Koolhydraten (NSP) in de veevoeding. Productschap Diervoeder, kwaliteitsreeks 20.

Van Soest, P. J. 1994. Nutritional Ecology of the Ruminant. 2 ed. Comstock Publ. Assoc., Ithaca, NY.

van Vuuren, A. M., F. Krol Kramer, R. A. van der Lee, and H. Corbijn, 1992. Protein digestion and intestinal amino acids in dairy cows fed fresh Lolium perenne with different nitrogen contents. J. Dairy Sci. 75:2215-2225.

van Vuuren, A. M. C. J. van der Koelen, H. Valk, and H. de Visser. 1993. Effects of partial replacement of ryegrass by low protein feeds on rumen fermentation and nitrogen loss by dairy cows. J. Dairy Sci. 76:2982-2993.

Waldo, D. R. 1986. Effect of forage quality on intake and forageconcentrate interactions. J. Dairy Sci. 69:617-631.

Wilman, D., and P. T. Wright. 1978. The proportions of cell content, nitrogen, nitrate-nitrogen and water-soluble carbohydrate in 3 grasses in the early stages of regrowth after defoliation with and without applied nitrogen. J. Agric. Sci., 91:381-394. 